\title{
Application of a Gas Chromatography/Luminol Detection System for Peroxyacetyl Nitrate Airborne Measurement
}

\author{
Bumju Khang, Joon Young Ahn ${ }^{1)}$, Dasol Song ${ }^{2)}$ and Gangwoong Lee ${ }^{2), *}$ \\ Centennial Technology Co., Ansan, Korea \\ ${ }^{1)}$ Climate \& Air Quality Research Department, National Institute of Environmental Research, Incheon, Korea \\ ${ }^{2)}$ Hankuk University of Foreign Studies, Department of Environmental Sciences, Yongin, Korea \\ *Corresponding author. Tel: +82-31-330-4273, E-mail: gwlee@hufs.ac.kr
}

\begin{abstract}
We constructed and tested an airborne peroxyacetyl nitrate (PAN) monitoring system based on luminol chemiluminescence detection with fast gas chromatography. This system allowed for simultaneous measurement of PAN and nitrogen dioxide $\left(\mathrm{NO}_{2}\right)$ with a time resolution of $<2 \mathrm{~min}$. Actual sample masses within the fixed volume sample loop at various altitudes and temperatures were adjusted to standard atmosphere, using measured pressures and temperatures. The airborne PAN measurement system was evaluated during two field studies above the southern Korean Peninsula in August and October 2009. The detection limit based on the ISO approach was 0.035 ppbv PAN, well below the observed concentrations of $0.185-1.49$ ppbv during these studies. Under these conditions, the PAN mixing ratios were positively correlated with $\mathrm{O}_{x}\left(\mathrm{O}_{x}=\mathrm{O}_{3}+\mathrm{NO}_{2}\right)$, with slopes varying between 0.014 and 0.033 and intercepts between 22.6 and $55.1 \mathrm{ppbv} \mathrm{O}_{\mathrm{x}}$. The intercepts corresponded roughly to background $O_{x}$ mixing ratios in central Europe; however, the slopes were above the range of slopes reported in other studies. We also enhanced the durability, safety, and ease of maintenance of the PAN monitoring system by redesigning the structure of the conventional luminol cell.
\end{abstract}

Key words: PAN, Airborne measurement, Luminol detection, Fast GC, Ozone

\section{INTRODUCTION}

Peroxyacetyl nitrate (PAN) is one of a class of common air pollutants formed by the action of sunlight on volatile organic compounds (VOCs) and nitrogen oxides $\left(\mathrm{NO}_{\mathrm{x}}\right)$. PAN is also present in polluted atmospheres and has been suggested as an indicator of photochemical smog along with ozone $\left(\mathrm{O}_{3}\right)$. Unlike $\mathrm{O}_{3}$, PAN does not have abundant natural sources in the stratosphere (Stephens, 1969). PAN is produced only from VOCs whose oxidation leads to acetyl radicals in the presence of nitrogen oxides, whereas $\mathrm{O}_{3}$ is formed through the oxidation of all VOCs. PAN and nitrogen dioxide $\left(\mathrm{NO}_{2}\right)$ play major roles in the chemistry of the troposphere at urban, regional, and global scales (Singh, 1985). PAN is in equilibrium with $\mathrm{NO}_{2}$ and the peroxyacetyl radical. This equilibrium is strongly temperature-dependent; PAN is more stable at colder temperature (Fischer and Nwankwoala, 1995; Roberts, 1990). At cold temperatures, PAN can act as an important transport mechanism for $\mathrm{NO}_{\mathrm{x}}$ and a source of remote $\mathrm{NO}_{2}$ (Gaffney and Marley, 1993; Gaffney et al., 1989; Singh, 1987). Among its chemical properties, low solubility in water (Gaffney et al., 1984) and low OH reactivity (Talukdar et al., 1995) give PAN a long atmospheric lifetime. Therefore, both PAN and $\mathrm{NO}_{2}$ are important atmospheric oxidants formed in the troposphere that affect air quality and can lead to global climate change (Gaffney and Marley, 1992).

PAN has been measured using a variety of methods (Gaffney et al., 1989). The most widely used method is the electron capture detector (ECD). This method has detection limits in the tens of ppt and uses packed or capillary columns for the analysis (Roberts, 1990; Gaffney et al., 1989). However, many atmospheric gases interfere with ECD signals, limiting the speed of the analysis to 10-30 min. Luminol detection of $\mathrm{NO}_{2}$ and PAN has been conducted using packed columns with air as a carrier gas (Burkhardt et al., 1988). Measurement of PAN after chromatographic separation and thermal conversion of PAN to $\mathrm{NO}_{2}$, followed by luminol detection of the generated $\mathrm{NO}_{2}$, has also been shown to be a sensitive method (Blanchard et al., 1990). Luminol methods using packed and capillary columns have been compared with the more conventional ECD chromatographic approach and have been found to agree to within 15-20\% (Blanchard et al., 1990). Be- 


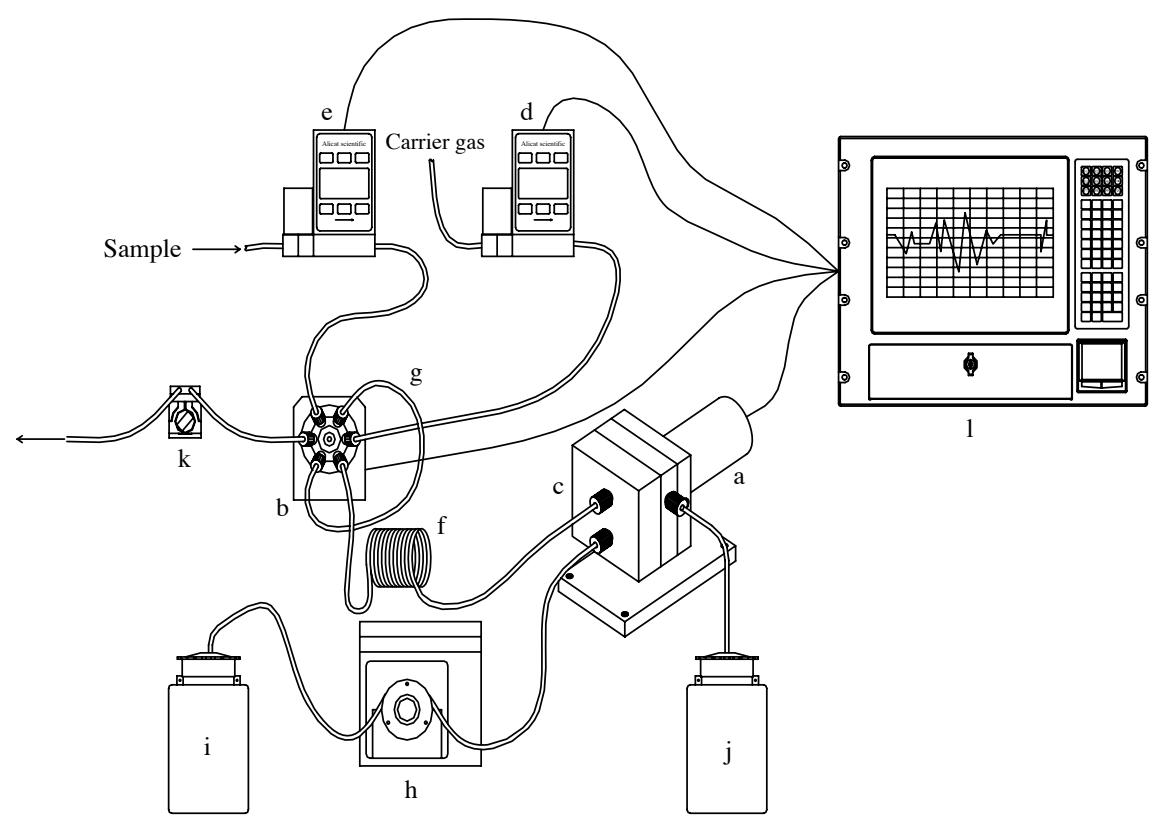

Fig. 1. Schematic diagram of the fast GC with luminol detector for PAN monitoring. (a) Photon counter, (b) sampling valve, (c) luminol cell, (d) mass flow controller for the carrier gas, (e) mass flow controller for the sample, (f) capillary column, (g) sample loop, (h) peristaltic pump, (i) luminol solution reservoir, (j) waste reservoir, (k) sampling diaphragm pump, (l) data acquisition system (LabVIEW).

cause luminol detection of PAN does not suffer from the oxygen interference that affects ECD, separation of $\mathrm{NO}_{2}$ and PAN can be accomplished in a much shorter analysis time (Gaffney et al., 1999; Gaffney et al., 1998). Marley et al. (2004) developed the prototype for simultaneous fast-response measurement of $\mathrm{NO}_{2}$ and PAN.

Airborne instrumentation for PAN measurement must meet several requirements. To apply the luminol method, improvements in sensitivity and increased contact of the column effluent with the luminol solution is needed. In addition, when on board an aircraft, the analysis time should be as short as possible to obtain good spatial resolution of the measurements and minimize thermal decomposition of PAN. Further challenges to be addressed include: 1) pressure variations in the aircraft cabin, which can lead to signal and baseline shifts; 2) decreasing ambient pressure with increasing flight altitude will reduce the injected air sample mass if the injection system does not compensate for pressure changes; and 3) aircraft operation places limits on weight, size, and electric power consumption of the instrument. The objective of this study was to construct and test an airborne PAN monitoring system based on luminol chemiluminescence detection with fast gas chromatography (GC), meeting the requirements stated above.

\section{MATERIALS AND METHODS}

We constructed a capillary fast GC with luminol detector optimized for high sampling frequencies to measure airborne PAN (Fig. 1). We selected all components based on the review paper of Marley et al. (2004) and designed the instrumentation to fit into a 19-inch sub-rack case for mobility, portability, and ease of installation. The sampling pump (Fig. 1k) was connected directly to the aircraft sampling manifold, which was held at a constant pressure of 12.1 psi by a mass flow controller (Fig. 1e). Two milliliters of ambient air were injected every 2 min through a 6-port valve (Fig. 1b) with a Teflon sampling loop (Fig. 1g). The analyzer was equipped with a capillary column (DB-1, 10 m, $530 \mu \mathrm{M}$ i.d., $1 \mu \mathrm{M}$ film thickness; Fig. 1f) for separation of PAN and $\mathrm{NO}_{2}$. Nitrogen gas (purity $99.999 \%$ ) was used as carried gas at a flow rate of $20 \mathrm{cc} / \mathrm{min}$. The chemiluminescence signal was detected by a gated photon counter (HC135-01, Hamamatsu) set at $850 \mathrm{~V}$. All peaks were stored on a computer and analyzed with LabVIEW software (National Instrument Co.). The PAN monitoring system was operated at $<35^{\circ} \mathrm{C}$. In previous study, combined uncertainties based on the ISO approach were quantified to identify the major sources for measurement uncertainty during the determination of PAN concentrations using this system (Khang et al., 2010). Under 


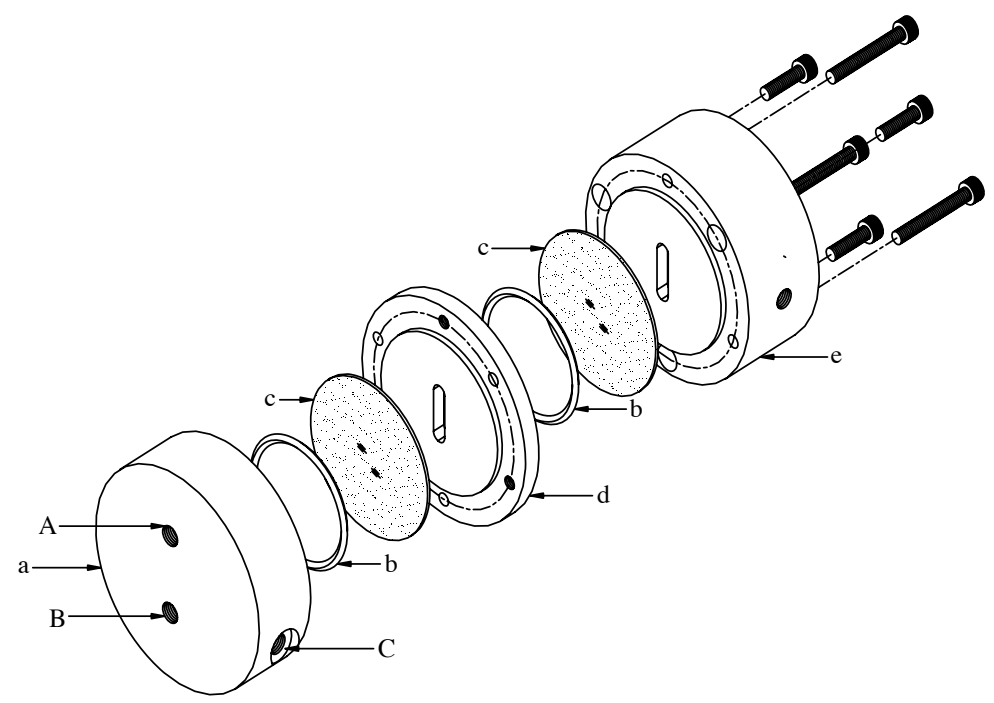

Fig. 2. Structure and assembly of the luminol cell. (A) Sample inlet, (B) Waste Outlet, (C) Luminol solution inlet, (a) Luminol reactor, (b) O-ring, (c) Window, (d) Reactor frame, (e) PMT bracket.

these conditions, the detection limit based on the ISO approach was $0.035 \mathrm{ppbv}$ PAN and the retention times of $\mathrm{NO}_{2}$ and PAN were 0.45 and $1.16 \mathrm{~min}$, respectively. $\mathrm{O}_{3}$ was measured with an ultraviolet absorption photometer (Model 49; Thermo Environmental Instruments, Inc.). The detector was equipped with a rapid-update EEPROM by the manufacturer, which allowed for a 4-s cycle time, 0 to $95 \%$ response time of 10 $\mathrm{s}$, and precision of $2 \mathrm{ppbv}$. The sensitivity of the UV photometer was quite stable, but instrument calibration was conducted between flights.

Previously developed PAN detectors have generally had a single quartz window between the photomultiplier tube (PMT) and the reaction cell (Marley et al., 2004). $1 \mathrm{mM}$ luminol solution is prepared in the strong base of $0.5 \mathrm{M} \mathrm{NaOH}$. If the quartz window is exposed to the luminol solution over the long term, the luminol can break the glass in the reactor cell. For this reason, the reactor cell must be washed with pure water after analysis. Because this solution is not entirely safe for long-term operation, we improved the durability of the PAN monitoring system by redesigning the luminol cell with double quartz glass windows between the luminol solution and the PMT. Fig. 2 shows the luminol cell as redesigned in this study, based on the luminol cell designed by Marley et al. (2004). PAN and $\mathrm{NO}_{2}$, after separation by the capillary column, enter the reaction cell in a carrier gas with stable flow, then are pumped out of the cell with luminol solution. The luminol cell has a symmetric structure front to back. The chemiluminescence reaction occurs in the front cap, which has three holes con-

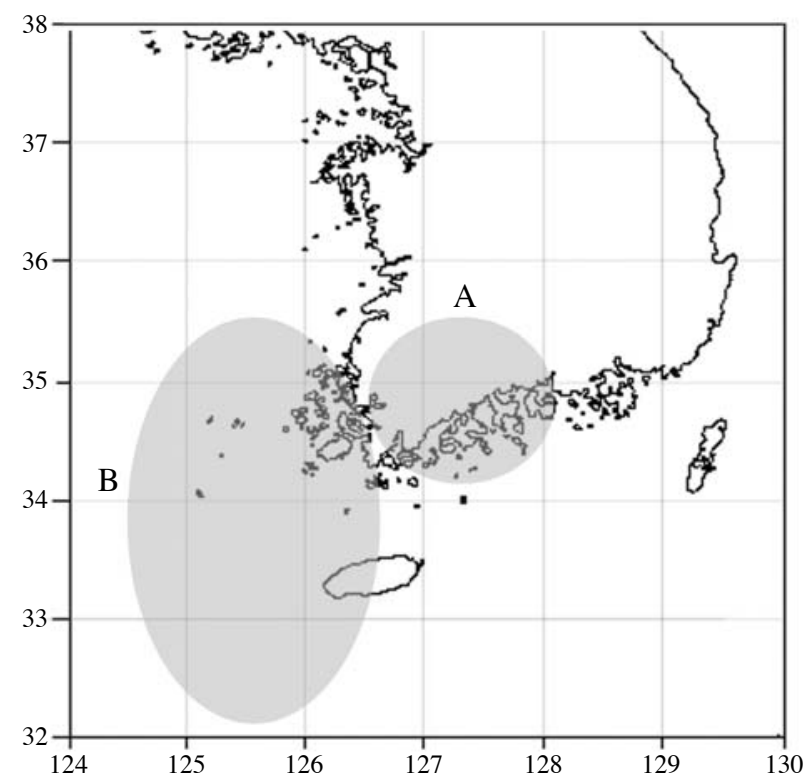

Fig. 3. Flight areas in this study. A region was above an industrial and urban area and $\mathrm{B}$ region was above the sea at southwest of Korea.

nected to the capillary column (Fig. 2a), waste reservoir (Fig. 2b), and luminol supply pump (Fig. 2c). The chemiluminescence emission is captured by the PMT, located in the PMT bracket (Fig. 2e). In addition, we added an o-ring and quartz window to the reactor frame to isolate the luminol reaction cell from the PMT. This duplicate structure enhances the safety and durability of the PAN measurement system, while poten- 
Table 1. Summary of the flights and average PAN, $\mathrm{NO}_{2}$ and $\mathrm{O}_{3}$ mixing ratios.

\begin{tabular}{|c|c|c|c|c|c|c|c|c|}
\hline $\begin{array}{l}\text { Flight } \\
\text { no }\end{array}$ & Area & $\begin{array}{c}\text { Description } \\
\text { (latitude, longitude) }\end{array}$ & $\begin{array}{l}\text { Main } \\
\text { altitude }\end{array}$ & $\begin{array}{l}\text { Start date } \\
\text { time }\end{array}$ & $\begin{array}{l}\text { End date } \\
\text { time }\end{array}$ & $\begin{array}{l}\mathrm{NO}_{2} \\
(\mathrm{ppb})\end{array}$ & $\begin{array}{l}\text { PAN } \\
(\mathrm{ppb})\end{array}$ & $\begin{array}{c}\mathrm{O}_{3} \\
(\mathrm{ppb})\end{array}$ \\
\hline 1 & A & $\begin{array}{r}35^{\circ} 21^{\prime} \mathrm{N} 126^{\circ} 70^{\prime} \\
\sim 34^{\circ} 22^{\prime} \mathrm{N} 128^{\circ} 19^{\prime}\end{array}$ & $\begin{array}{l}500 \mathrm{~m} \\
900 \mathrm{~m}\end{array}$ & $\begin{array}{c}\text { 01-Aug } \\
12: 28\end{array}$ & $\begin{array}{c}\text { 01-Aug } \\
16: 19\end{array}$ & 14.07 & 0.385 & 61.86 \\
\hline 2 & A & $\begin{array}{r}35^{\circ} 53^{\prime} \mathrm{N} 126^{\circ} 98^{\prime} \\
\sim 34^{\circ} 18^{\prime} \mathrm{N} 128^{\circ} 17^{\prime}\end{array}$ & $\begin{array}{l}500 \mathrm{~m} \\
900 \mathrm{~m}\end{array}$ & $\begin{array}{l}\text { 05-Aug } \\
12: 34\end{array}$ & $\begin{array}{l}\text { 05-Aug } \\
15: 42\end{array}$ & 10.89 & 0.185 & 52.88 \\
\hline 3 & A & $\begin{array}{r}35^{\circ} 53^{\prime} \mathrm{N} 127^{\circ} 05^{\prime} \\
\sim \\
4^{\circ} 21^{\prime} \mathrm{N} 128^{\circ} 17^{\prime} \\
\end{array}$ & $\begin{array}{l}500 \mathrm{~m} \\
660 \mathrm{~m}\end{array}$ & $\begin{array}{c}\text { 10-Aug } \\
12: 37\end{array}$ & $\begin{array}{c}10-\text { Aug } \\
15: 54\end{array}$ & 10.11 & 0.198 & 40.11 \\
\hline 4 & B & $\begin{array}{r}34^{\circ} 79^{\prime} \mathrm{N} 124^{\circ} 48^{\prime} \\
\sim 32^{\circ} 12^{\prime} \mathrm{N} 126^{\circ} 18^{\prime}\end{array}$ & $\begin{array}{r}930 \mathrm{~m} \\
\sim 980 \mathrm{~m}\end{array}$ & $\begin{array}{c}16-O c t \\
13: 00\end{array}$ & $\begin{array}{l}16-O c t \\
15: 44\end{array}$ & 2.48 & 0.516 & 68.15 \\
\hline 5 & B & $\begin{array}{r}35^{\circ} 51^{\prime} \mathrm{N} 124^{\circ} 51^{\prime} \\
\sim 33^{\circ} 02^{\prime} \mathrm{N} 126^{\circ} 82^{\prime}\end{array}$ & $\begin{array}{r}930 \mathrm{~m} \\
\sim 995 \mathrm{~m}\end{array}$ & $\begin{array}{l}18-O c t \\
13: 00\end{array}$ & $\begin{array}{l}18-O c t \\
17: 26\end{array}$ & 5.11 & 0.614 & 59.72 \\
\hline 6 & B & $\begin{aligned} & 34^{\circ} 31^{\prime} \mathrm{N} 124^{\circ} 57^{\prime} \\
\sim & 32^{\circ} 94^{\prime} \mathrm{N} 126^{\circ} 52^{\prime}\end{aligned}$ & $\begin{array}{l}660 \mathrm{~m} \\
950 \mathrm{~m}\end{array}$ & $\begin{array}{l}19-\text { Oct } \\
15: 34\end{array}$ & $\begin{array}{l}19-\text {-Oct } \\
17: 32\end{array}$ & 5.51 & 0.359 & 45.47 \\
\hline
\end{tabular}
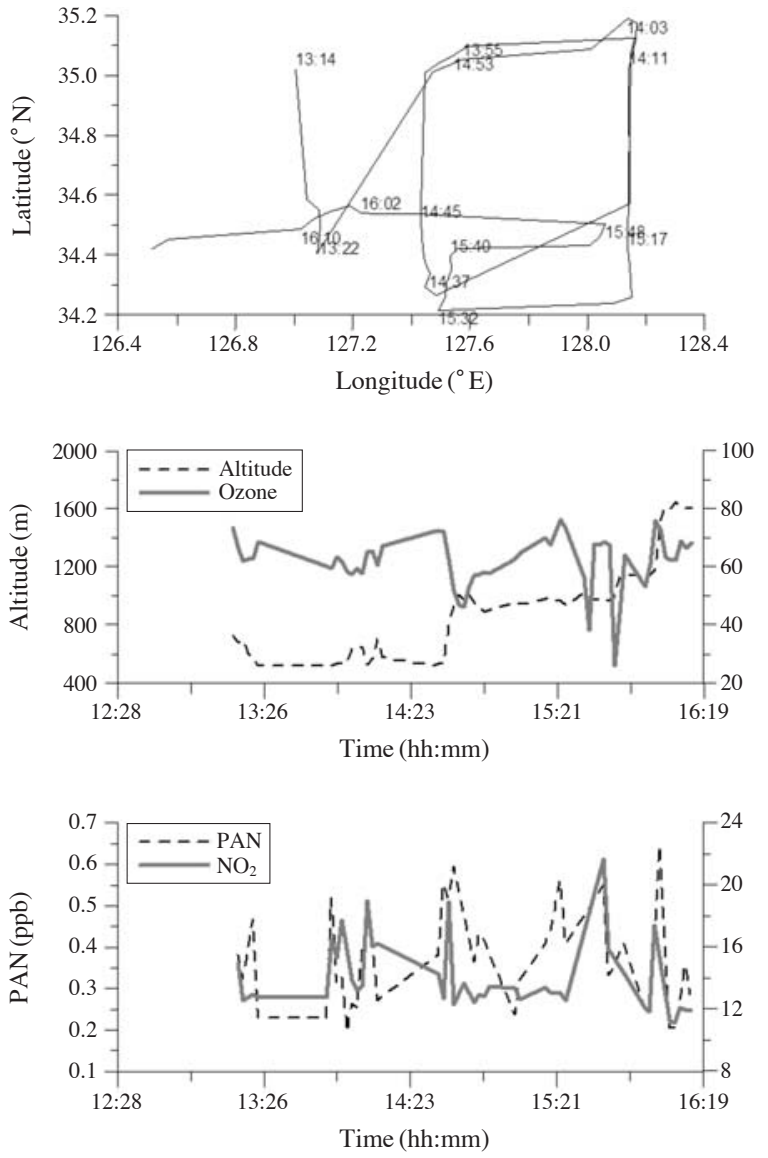

Fig. 4. Horizontal and vertical flight tracks and $\mathrm{PAN}, \mathrm{NO}_{2}$, and $\mathrm{O}_{3}$ measurements on 1 August 2009.

tially reducing the sensitivity of the PMT. For an aircraft platform, a mass flow controller is needed to compensate for the temperature and pressure of the sam-
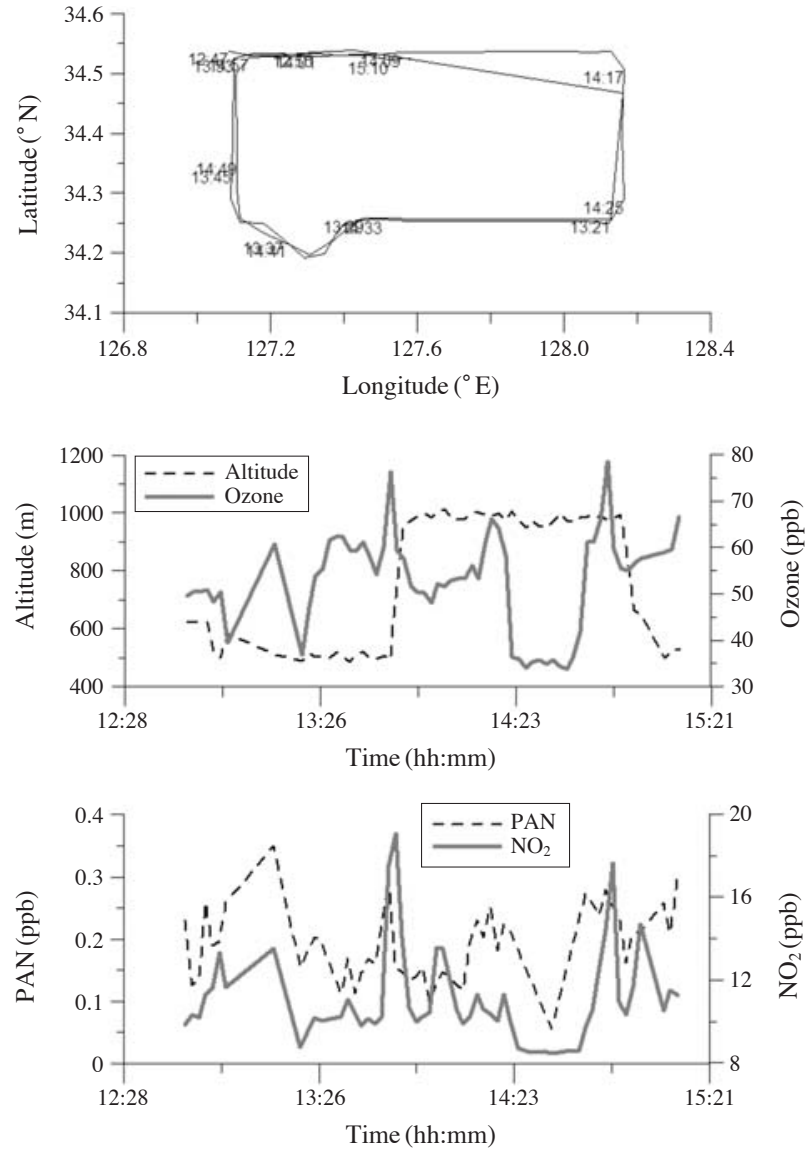

Fig. 5. Horizontal and vertical flight tracks and PAN, $\mathrm{NO}_{2}$, and $\mathrm{O}_{3}$ measurements on 5 August 2009.

ple. The temperature and pressure are measured by a digital flow controller when the samples are taken, which enables stabilization of the sample pressure in 
flight. The airborne PAN system was contained in a 19-inch rack case designed to fit in a standard instrument rack. The carrier gas was provided by a refillable gas cylinder attached to the back of the rack mount. The overall system weight was under $21 \mathrm{~kg}$ for portability and safety in the aircraft.

\section{RESULTS AND DISCUSSION}

\section{1 PAN Airborne Measurement}

We evaluated the performance of the airborne PAN monitoring system during two field studies above the southern Korean Peninsula in August and October 2009. Fig. 3 and Table 1 show the flight areas and altitudes. Field A was above an industrial complex and urban area in southern Korea and field B was above the sea at southwest of Korea. Warm air was transported into the study area due to a high-pressure system originating in China. Much of the experimental period was under the influence of a continental anticyclone,
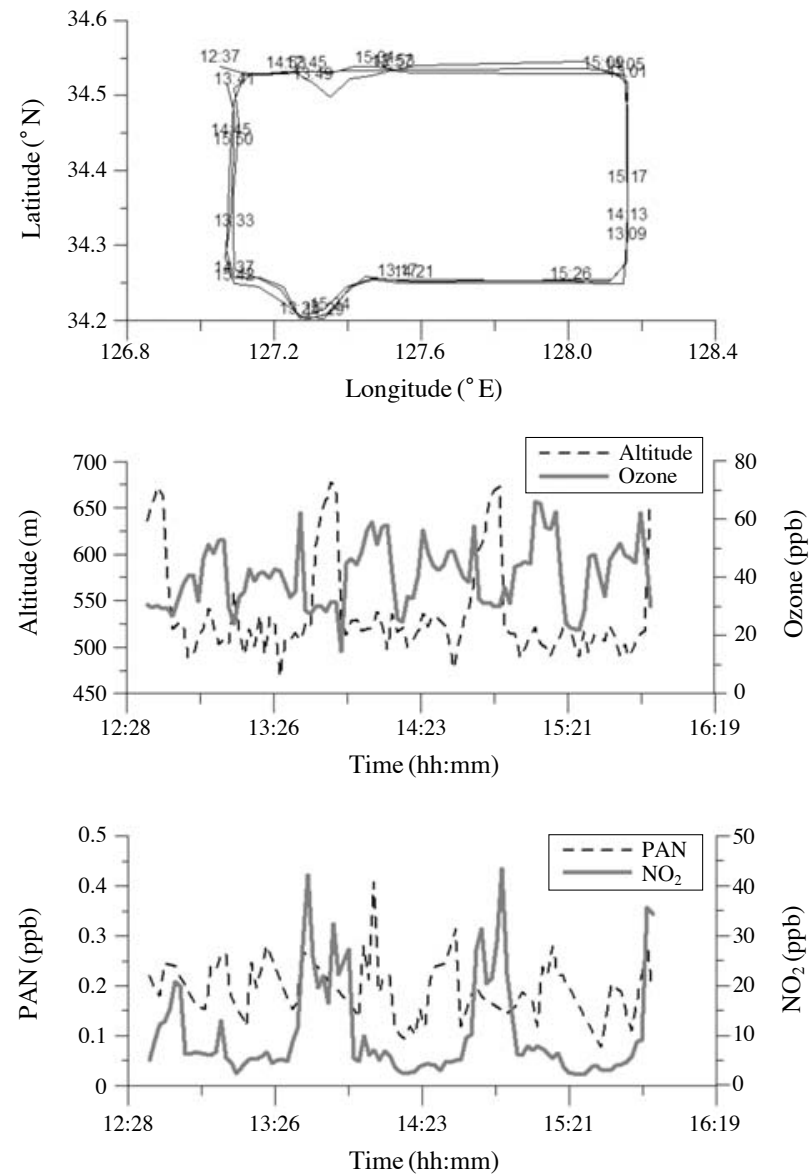

Fig. 6. Horizontal and vertical flight tracks and PAN, $\mathrm{NO}_{2}$, and $\mathrm{O}_{3}$ measurements on 10 August 2009. carrying yellow dust from China on westerly winds.

Figs. 4-9 show the horizontal and vertical tracks of all flights with altitude, as well as the measured PAN, $\mathrm{NO}_{2}$, and $\mathrm{O}_{3}$ mixing ratios. Table 1 summarizes the average mixing ratios for PAN, $\mathrm{NO}_{2}$, and $\mathrm{O}_{3}$ during the individual flights. All flights were conducted below an altitude of $1,000 \mathrm{~m}$ during the day on dry sunny days. PAN and $\mathrm{NO}_{2}$ were measured simultaneously with time resolution of $<2 \mathrm{~min}$, an improvement of 5-fold over ECD. $\mathrm{NO}_{2}$ and PAN were detected separately at $0.2 \mathrm{~min}$ and $1.3 \mathrm{~min}$. During the three flights on 1, 2, and 10 August, the air temperature was 23$29^{\circ} \mathrm{C}$. The PAN mixing ratios were $0.1-0.6 \mathrm{ppbv}$, similar to the average of ratios measured in European aircraft studies at similar altitudes (Schmidt et al., 1998). The maximum concentrations of $\mathrm{O}_{3}$ and $\mathrm{NO}_{2}$ occurred at the same position $\left(127.1^{\circ} \mathrm{E}, 34.5^{\circ} \mathrm{N}\right)$ over the industrial complex. During the three flights on 16, 18, and 19 October, the air temperature was about 21.2 ${ }^{\circ} \mathrm{C}$. The PAN mixing ratios were $>1.1 \mathrm{ppbv}$, higher than the flights in August.
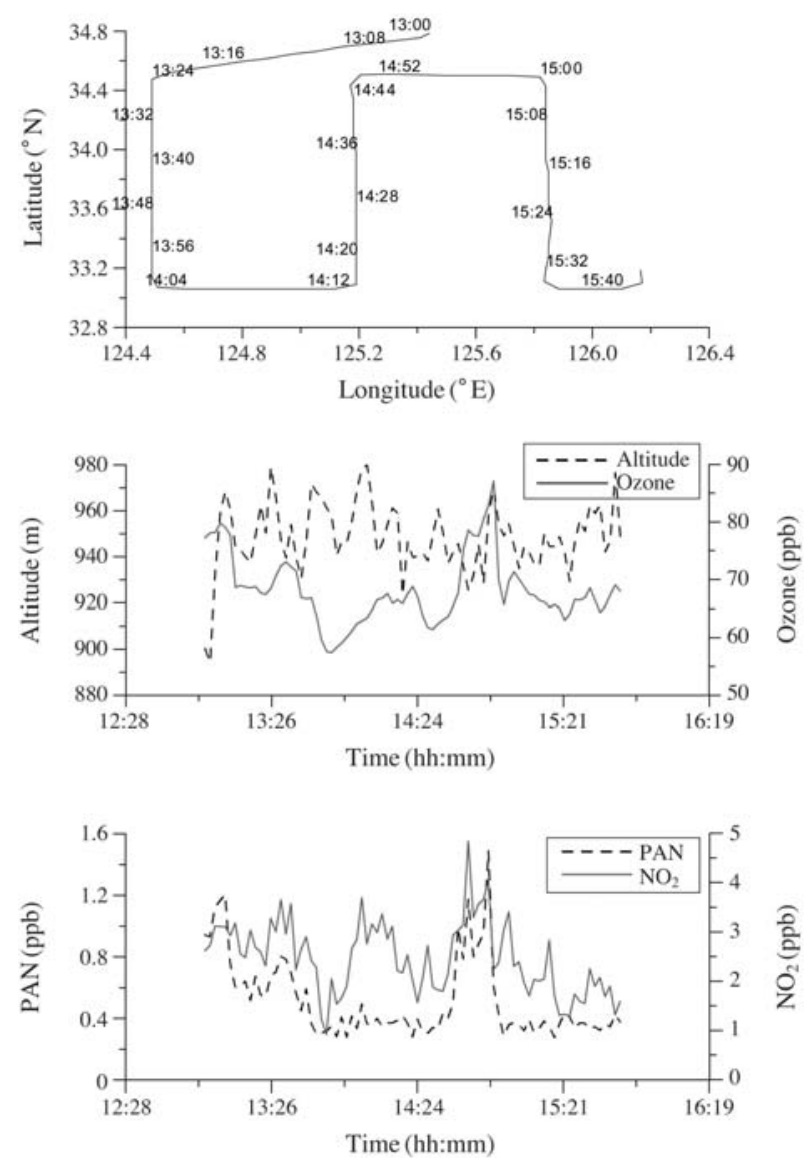

Fig. 7. Horizontal and vertical flight tracks and $\mathrm{PAN}, \mathrm{NO}_{2}$, and $\mathrm{O}_{3}$ measurements on 16 October 2009. 

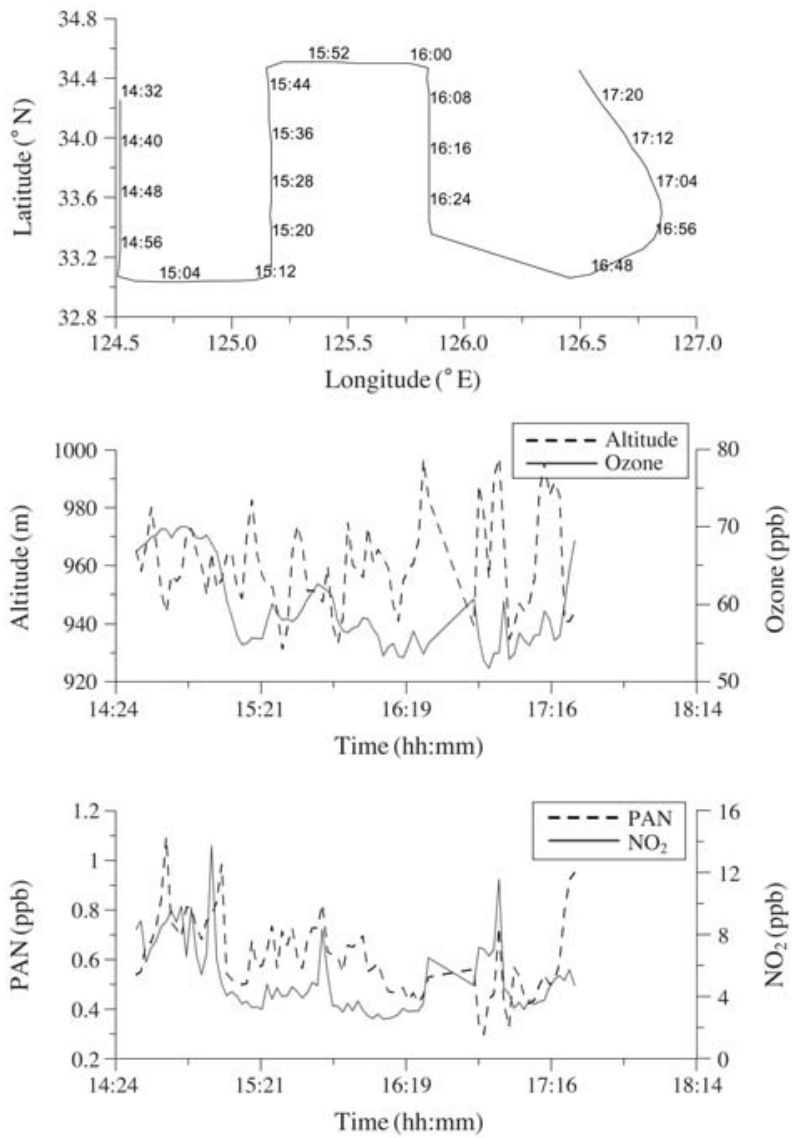

Fig. 8. Horizontal and vertical flight tracks and PAN, $\mathrm{NO}_{2}$, and $\mathrm{O}_{3}$ measurement on 18 October 2009.

\section{2 Relationship between PAN and $\mathrm{O}_{3}$}

Airborne studies of the relationship between PAN and $\mathrm{O}_{3}$ mixing ratios are influenced by the horizontal and vertical variability of both compounds in air masses differing by precursor load and photochemical age. Rappengluck et al. (1993) reported that the mean ratio of $\mathrm{O}_{3}$ to PAN is about 15-30 in polluted air masses (Shepson et al., 1992; Altshuller, 1983), and Kourtidis et al. (1993) reported that the correlation between PAN and $\mathrm{O}_{3}$ at ground level is typically strongly positive (Shepson et al., 1992; Wunderli and Gehring, 1991; Ridley et al., 1990). As a result, classification of airborne PAN and $\mathrm{O}_{3}$ data by air mass origin, precursor load, and degree of photochemical processing is generally necessary if $\mathrm{PAN}-\mathrm{O}_{3}$ relationships are to be investigated (Ridley et al., 1990). In practice, reliable classification of aircraft data according to these criteria can rarely be achieved. However, without such classification, $\mathrm{PAN}-\mathrm{O}_{3}$ correlations that may exist in photochemically aged air masses are less pronounced due to the loss of $\mathrm{O}_{3}$, which reacts with $\mathrm{NO}$ in freshly polluted air masses, while PAN is much more stable
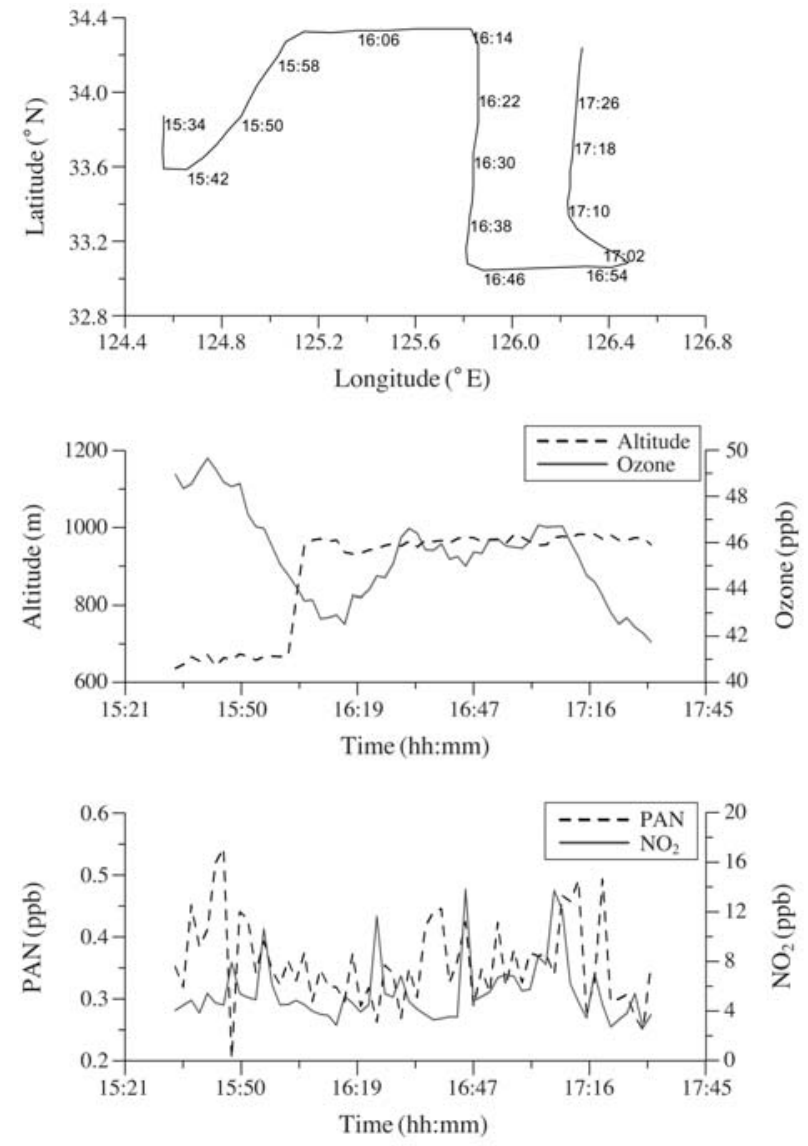

Fig. 9. Horizontal and vertical flight tracks and $\mathrm{PAN}, \mathrm{NO}_{2}$, and $\mathrm{O}_{3}$ measurements on 19 October 2009.

in cold air parcels. Kley et al. (1994) demonstrated that comparing PAN with $\mathrm{O}_{\mathrm{x}}\left(\mathrm{O}_{3}+\mathrm{NO}_{2}\right)$ rather than $\mathrm{O}_{3}$ can reduce this interference. In meteorological terms, strong positive correlations between PAN and $\mathrm{O}_{\mathrm{x}}$ are expected in stable wind fields, leading to formation of well-defined regions upwind and downwind of anthropogenic sources within the flight area. Such situations provide the large range of PAN and $\mathrm{O}_{3}$ mixing ratios needed to establish significant correlations.

Data for most of the flights showed relatively poor correlations between PAN and $\mathrm{O}_{3}$, except for 16 and 18 October. Both of these flights were conducted at various altitudes, while the other flights maintained a similar altitude throughout. Fig. 10 shows correlations between PAN and $\mathrm{O}_{\mathrm{x}}$. The slopes of the correlations varied between 0.014 and $0.033 \mathrm{ppbv} \mathrm{O}_{\mathrm{x}} / \mathrm{ppbv} \mathrm{PAN}$, wider than the range previously reported $(0.015$ 0.030; Schmidt et al., 1998; Rappengluck et al., 1993; Shepson et al., 1992; Ridley et al., 1990; Altshuller, 1983). When the PAN mixing ratios were 0 for the October flights, the background values of $\left(\mathrm{O}_{\mathrm{x}}\right)_{0}$ were 

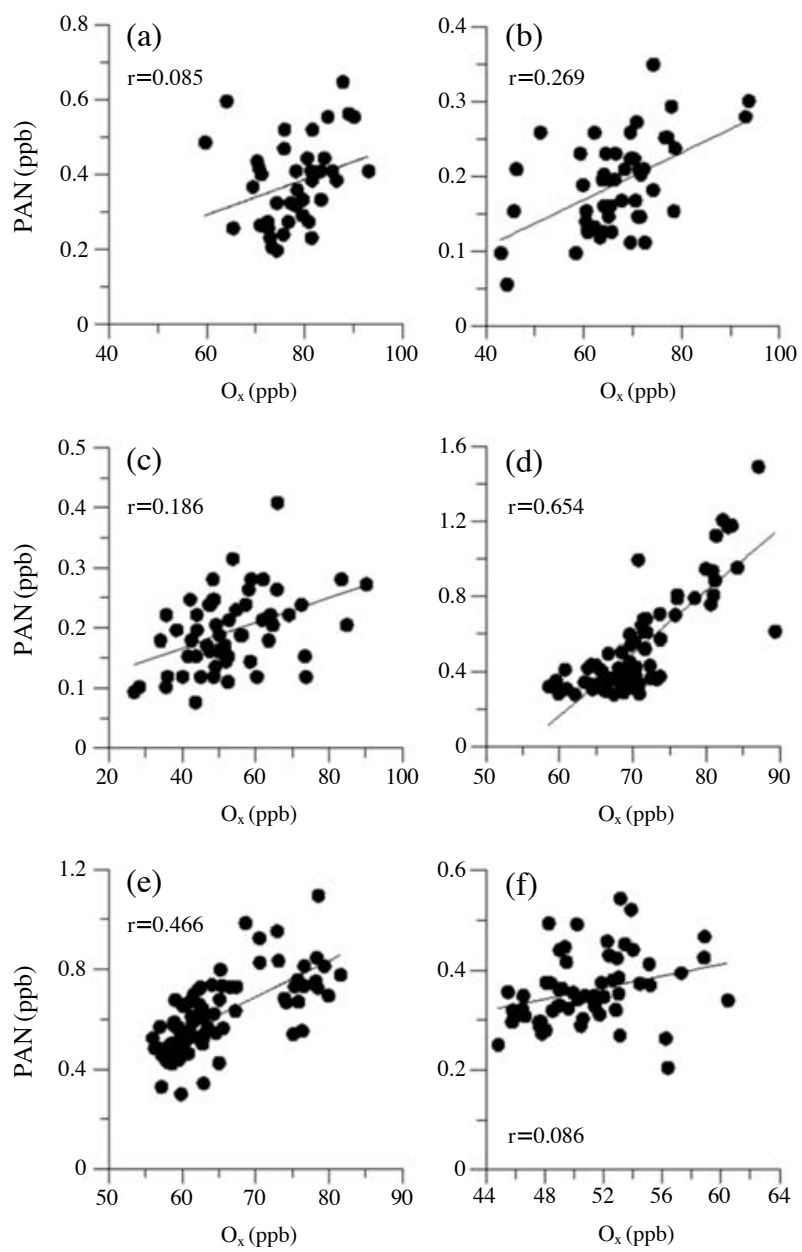

Fig. 10. Correlations between PAN and Ox on (a) 1 August, (b) 5 August, (c) 10 August, (d) 16 October, (e) 18 October, and (f) 19 October.

22.6 and $55.1 \mathrm{ppbv}$, varying more than the European background $\mathrm{O}_{3}$ mixing ratio in September of about 35 ppbv reported by Volz and Kley (1988). Despite high $\mathrm{O}_{3}$ with or without PAN correlations, the August flights did not yield background values, whereas the October flights showed strong correlations between PAN and $\mathrm{O}_{\mathrm{x}}$, yielding background values. We suggest that urban and industrial areas may be more favorable for generation of PAN than $\mathrm{O}_{3}$. It appears that the VOCs emitted from urban areas are important sources of PAN production compared to in the marine environment. PAN is also a strong indicator of photochemical oxidant production from anthropogenic pollutants.

The best correlation between PAN and $\mathrm{O}_{\mathrm{x}}$ was found for the afternoon flight on 16 October. Fig. 11 illustrates the relative importance of $\mathrm{NO}_{2}$ and temperature in determining the relationship between PAN and $\mathrm{O}_{3}$. From the lower left to the upper right, the correla-

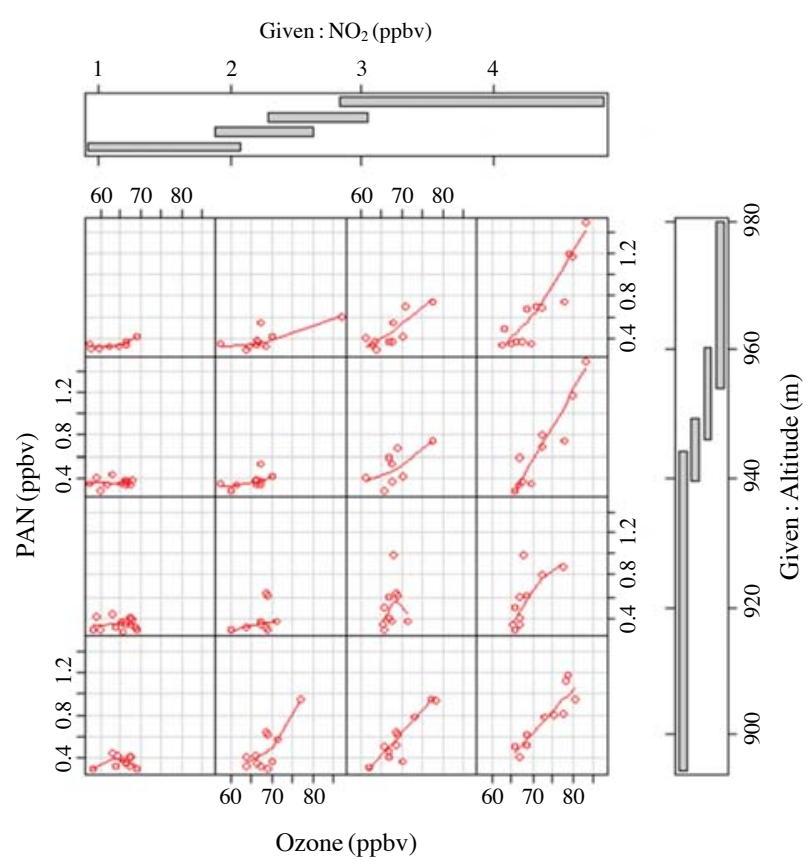

Fig. 11. Correlations between $\mathrm{PAN}$ and $\mathrm{O}_{3}$ with $\mathrm{NO}_{2}$ and altitude on 16 October.

tion between PAN and $\mathrm{O}_{3}$ was strengthened by increasing concentrations of $\mathrm{NO}_{2}$, temperature, and altitude. PAN and $\mathrm{O}_{3}$ were highly correlated when the $\mathrm{NO}_{2}$ concentration was $>3$ ppbv at high altitude.

\section{CONCLUSIONS}

We constructed an airborne PAN monitoring system based on chemiluminescence detection with fast GC. We modified the structure of the luminol cell with a duplicate quartz window to protect the PMT against the luminol solution and enhance the safety and durability of the instrument. The instrument allowed for continuous measurement of PAN and $\mathrm{NO}_{2}$ within 2 min. Further improvement in the instrumentation will be accomplished by cooling the system to minimize the thermal decomposition of PAN and to reduce the background noise from the photomultiplier tubes.

Airborne observations were conducted to evaluate this instrument over the southern Korean Peninsula in August and October 2009. The two flight areas were characterized as marine and urban/industrial environments. We measured the concentrations of PAN, $\mathrm{NO}_{2}$, and $\mathrm{O}_{3}$ throughout all flights. The relationship between PAN and $\mathrm{O}_{3}$ was more sensitive to $\mathrm{NO}_{2}$ than to altitude, with a threshold of $3 \mathrm{ppbv} \mathrm{NO}_{2}$ on the afternoon flight of 16 October. We found that the $\left(\mathrm{O}_{\mathrm{x}}\right)_{0}$ background value for the urban/industrial environment was higher 
than that of the marine environment. We conclude that urban or industrial areas are sources with higher potential for generation of PAN than the marine environment, confirming that PAN is a strong indicator of photochemical oxidant production from anthropogenic pollutants.

\section{ACKNOWLEDGEMENT}

This work was supported by a Grant from the National Research Foundation of Korea (NRF-2010-0010 773).

\section{REFERENCES}

Altshuller, A.P. (1983) Measurements of the products of atmospheric photochemical reactions in laboratory studies and in ambient air relationships between ozone and other products. Atmospheric Environment 17, 23832427.

Blanchard, P., Shepson, P.B., Schiff, H.I., Bottenheim, J.W., Gallant, A.J., Drummond, J.W., Wong, P. (1990) A comparison of calibration and measurement techniques for gas chromatographic determination of atmospheric peroxyacetyl nitrate. Atmospheric Environment 24A, 2839-2846.

Burkhardt, M.R., Maniga, N.I., Stedman, D.H., Paur, R.J. (1988) Gas chromatographic method for measuring nitrogen dioxide and peroxyacetyl nitrate in air without compressed gas cylinders. Analytical Chemistry 60, 816-819.

Finlayson-Pitts, B.J., Senum, G.I. (1984) Atmospheric Chemistry. John Wiley and Sons, New York.

Gaffney, J.S., Bornick, R.M., Chen, Y.-H., Marley, N.A. (1998) Capillary gas chromatographic analysis of nitrogen dioxide and PANs with luminol chemiluminescence detection. Atmospheric Environment 32, 11451154.

Gaffney, J.S., Fajer, R., Senum, G.L. (1984) An improved procedure for high purity gaseous peroxyacetyl nitrate production: Use of heavy lipid solvents. Atmospheric. Environment 18, 215-218.

Gaffney, J.S., Marley, N.A. (1992) Potential changes in atmospheric chemistry in the decades ahead: Climate and biosphere interactions and feedbacks. In Precipitation Scavenging and Atmosphere-Surface Exchange. The Summers Volume: Applications and Appraisals (Schwartz, S.E. and Slinn, W.G.N. Eds), Vol. 3. Hemisphere Publishing Corporation, pp. 1735-1743.

Gaffney, J.S., Marley, N.A. (1993) Measurement of peroxyacetyl nitrate at a remote site in the southwestern United States: tropospheric implications. Environmental Science and Technology 27, 1905-1910.

Gaffney, J.S., Marley, N.A., Prestbo, E.W. (1989) Peroxyacyl nitrates (PANS): their physical and chemical properties. In Handbook of Environmental Chemistry (Hutzinger, O.Ed), Vol. 4/Part B. Springer-Verlag, Berlin, Germany, pp. 1-38.

Gaffney, J.S., Marley, N.A., Steele, H.D. (1999) Aircraft Measurement of Nitrogen Dioxide and PAN using luminol chemiluminescence with fast capillary gas chromatography. Environmental Science and Technology 33(19), 3285-3289.

Khang, B., Choi, H., Lee, G. (2010) Luminol/GC-based Peroxyacetyl Nitrate Measurement and Its Uncertainty Estimation. Journal of Environmental Science and Engineering 13, 15-20.

Kley, D., Geiss, H., Mohnen, V.A. (1994) Tropospheric ozone at elevated sites and precursor emissions in the United States and Europe. Atmospheric Environment 28, 149-158.

Kourtidis, K.A., Fabian, P., Zerefos, C., Rappengluck, B. (1993) Peroxyacetyl nitrate (PAN), peroxypropionyl nitrate (PPN) and PAN/ozone ratio measurements at three sites in Germany. Tellus 45B, 442-457.

Libuda, H.G., Zabel, F. (1995) UV absorption cross section of acetyl peroxynitrate and trifluoroacetyl peroxynitrate at $298 \mathrm{~K}$. Berichte der Bunsen-Gesellschaft fuer Physikalische Chemie 99, 1205-1213.

Marley, N.A., Gaffney, J.S., White, R.V., Rodriguez-Cuadra, L., Herndon, S.E., Dunlea, E., Volkamer, R.M., Molina, L.T., Molina, M.J. (2004) Fast gas chromatography with luminol chemiluminescence detection for the simultaneous determination of nitrogen dioxide and peroxyacetyl nitrate in the atmosphere. Review of Scientific Instruments 75, 4595-4605.

Rappengluck, B., Kourtidis, K., Fabian, P. (1993) Measurements of ozone and peroxyacetyl nitrate (PAN) in Munich. Atmospheric Environment 27B, 293-305.

Ridley, B.A., Shetter, J.D., Walega, J.G., Madronich, S., Elsworth, C., Grahek, M., Fehsenfeld, F.C., Norton, R.B., Parrish, D.D., Hubler, G., Buhr, M., Williams, E.J., Allwine, E.J., Westberg, H. (1990) The behaviour of some organic nitrates at Boulder and Niwot Ridge, Colorado. Journal of Geophysical Research 95, 1394913961.

Roberts, J.M. (1990) Atmospheric chemistry of organic nitrate. Atmospheric Environment 24A, 243-287.

Schmidt, R.W.H., Slemr, F., Schurath, U. (1998) Airborne PAN and PPN measurements during tract 1992. Atmospheric Environment 32(17), 1203-1227.

Shepson, P.B., Hastie, D.R., So, K.W., Schmit, H.I. (1992) Relationships between PAN, PPN and ozone at urban and rural sites in Ontario. Atmospheric Environment 26A, 1259-1270.

Singh, H.B. (1985) Global distribution of peroxyacetyl nitrate. Nature 318, 347-349.

Singh, H.B. (1987) Reactive nitrogen in the troposphere: Chemistry and transport of NO. and PAN. Environmental Science and Technology 21, 320-327.

Stephens, E.R. (1969) The formation, reactions and properties of peroxyacylnitrates (PANs) in phtochemical air pollution. Environmental Science and Technology 1, 
119-146.

Talukdar, R., Rudich, Y., Burkholder, J.B. (1995) Reaction of Methylbutenol with Hydroxyl Radical- Mechanism and Atmospheric Implications. Journal of Physical Chemistry 99(32), 12188-12194.

Volz, A., Kley, D. (1988) Evaluation of the Montsouris series of ozone measurements made in nineteenth century. Nature 332, 240-243.

Wunderli, S., Gehrig, R. (1991) Influence of temperature of formation and stability of surface PAN and ozone. A two year field study in Switzerland Atmospheric Environment 8, 1599-1608.

(Received 14 March 2013, revised 21 May 2013, accepted 29 May 2013) 